\title{
Gender Differences in Attitude Toward Students with Disabilities Among Primary Students in Jakarta
}

\author{
Rachel Ullynaria Doreen, Farida Kurniawati \\ Department of Educational Psychology \\ Universitas Indonesia \\ Depok, Indonesia \\ racheldoreens@gmail.com, farida1@ui.ac.id
}

\begin{abstract}
This research aims to compare the differences in attitude towards students with disabilities between boys and girls in primary inclusive school in Jakarta. This study employed a quantitative approach study and cross-sectional design. A total of 266 regular students (147 boys and 149 girls), aged 9 -13 years old, from five different inclusive public schools across Jakarta and Depok have participated in this study. Students' attitude toward students with disabilities was measured with ChedokeMcMaster Attitudes toward Children with Handicaps (CATCH) and adapted in the Bahasa version. It consists of 18 items and it has good internal reliability Cronbach's alpha .77. The data were analyzed by using Independence Samples t-test. The result showed that there was no significant difference in attitude toward the students with disabilities between boys and girls $(t(264)=-$ 1.921, $\mathrm{p}=\mathbf{0 . 0 5 6}$ ). It means that there is no difference of attitude towards students with disabilities among girls and boys in primary students in Jakarta. In general, most students are indicated with neutral attitudes toward students with disabilities. Hence, the findings of this study help to change the faulty perception that boys have a more negative attitude toward students with disabilities compared to girls.
\end{abstract}

Keywords-gender, attitudes, disabilities, inclusive education, primary school.

\section{INTRODUCTION}

Disability is a complex and wide-ranging issue. People with disability usually have functional difficulties to live in an unaccommodating environment. It means that some people with disabilities need particular services and facilities to be able to do their activities like regular people. One of the most critical facilities is the educational system. In Indonesia, every citizen has the same right to obtain an education. It is stated in the 1945 Republic of Indonesia's Constitution chapter 31. This statement comes into understanding that citizens including people with disabilities and have the right to have the education which designed according to their limitations.

The terms 'special needs school' or 'mainstreaming' are known as the school for children with disabilities, but this educational setting still excludes the children with disabilities to physically and socially excluded from the regular student [1]. Nevertheless, this approach is changing along with the trend towards the inclusive education of children within regular education settings.
'Inclusive Education' is the term used to describe teaching students with and without disabilities in the same environment [2]. Ref. [3] stated that being educated alongside with typically developing peers can prevent discriminative attitudes toward students with disabilities. This kind of education requires the system to be adapted to be able to cope with this diversity [4]. Consequently, regular students must be adequately prepared to provide the necessary support and environment to meet the diverse needs of students.

By attending schools together, students, with and without disabilities, can experience many social benefits [5]. Students will not only have the opportunity to academically learning the same thing but also have more possibilities to build interactions and friendships. A positive relationship that is built through friendship will improve academic, language and cognitive aspects of students with disabilities as well as their behavior and social skills [6], [7]. Moreover, inclusive environment also gives regular student opportunities to have direct experience with students with disabilities, so they can learn to have empathy, help and care for each other [8], [9].

The problem is being together in the same environment as the regular students do not automatically result in positive acceptance [10]. Students with disabilities usually have difficulties to socially participating inside the classroom and also in obtaining acceptance by their peers [11], [12]. Meanwhile, peer acceptance and friendships of students (regardless of a disability) in childhood is often regarded as a predictor of development outcomes. Acceptance by peers is particularly crucial for children in primary school because the size of friendship groups also increases with the grade in elementary school (grades $1-4$ ), and peaks during the middle school years [13]

Children with disabilities are also often confronted with negative attitudes by the regular students in inclusive education. As a result, it can have a dramatic effect in student's life, such as low acceptance, few friendships, loneliness and being rejected and/or bullied [10], [14], [15]. Consequently, rejection and tendency of being befriended by peers may lead to adverse long-term outcomes, like depression and other mental health issues [16], [17].

It is still not clear why students with disabilities experience difficulties in making and keeping friends. Ref [18] suggested the social participation is linked with attitudes towards peers 
with a disability. Ref [10] showed that attitudes are a key factor in the acceptance of students with disabilities in regular education. These studies underlying the importance of positive attitudes in the peer group when implementing inclusive education.

Ref [19] stated that an attitude is an idea charged with emotion which predisposes a class of actions to a particular class of social situations. This definition has three components: the idea (cognitive component), the emotion attached to it (affective component), and the predisposition to action (behavioral component). In this study, the cognitive component consists of an individual's beliefs or knowledge about disabilities. Feelings about students with disabilities refer to the affective component. With regard to the behavioral component, this reflects someone's predisposition to act towards students with disabilities in a particular way.

Several personal and external variables were found relating to attitudes toward students with disabilities, such as gender, age, experience with inclusive education, knowledge about disabilities and parental influence [10]. There was a mixed reaction among researchers on gender differences in attitudes toward individuals with disabilities. Generally, it is argued that girls appear to be more accepting of individuals with disabilities than boys [20] - [22]. On the other hand, some studies also found that girls and boys were about equal in their views toward individuals with disabilities [23], [24].

This association between attitudes toward disabilities and gender is unclear and certain questions are remained omitted and unanswered. First, these results indicate that the performed studies show mixed outcomes for primary school student attitudes toward students with disabilities. Second, it is unknown to what extent gender differences are related to the attitudes of students toward students with disabilities. Third, study about gender differences in primary inclusive school is still very limited in Indonesia. This resulted in the following research questions for this current study: Does gender relate to the attitudes of regular students toward students with disabilities? Based on previous research, we expect to find that boys' attitude toward students with disabilities was lower compared to girl students. With regard to the classification of attitudes, it is expected that participants to hold neutral to positive attitudes towards students with disabilities.

\section{METHOD}

This study is a quantitative approach study and crosssectional design was being used. A total number of 266 regular students took part in this study, 147 boys $(M=46.17$, $\mathrm{SD}=.42)$ and 119 girls $(\mathrm{M}=47.31, \mathrm{D}=.40)$, with ages ranging from 9 to 12 years old drawn from five primary inclusive schools in Jakarta and Depok. Primary schools in Indonesia contain single grades 1-6. In our study, the participants are taken from the 4 th -5 th grades.

In order to select participants to participate, we drew up four selection criteria: (1) Regular primary school (students 912 years old); (2) Does not have any disabilities; (3) Learning in the same class with students with disabilities; (4) Never given any intervention or awareness about disabilities.
The attitudes of primary school students towards students with disabilities were assessed using the measurement tools, namely, Chedoke-McMaster Attitudes Towards Children With Handicaps (CATCH) (age 8-13). This measurement was developed by [25] and adapted in the Bahasa version. It is based on the component model of attitudes proposed by Triandis as cited in [25] which consists of three dimensions: a) the affective component, b) the implied behavioral component, and finally, c) the cognitive component. It contains 23 items, 12 items in each component with an equal number of positively and negatively worded statements. The items are arranged in a random order, alternating positive and negative statements. Factor and total scores are derived by summing items, dividing sums by the number of items, and multiplying by 10 . A high score represents a more positive attitude [25].

In this study we only use 18 items based on the results of validity tests that have been conducted, there are 5 items that do not meet the criteria of validity and cannot be used in the research. The CATCH Scale measuring instrument used in the study demonstrates good internal consistency reliability, in which Cronbach alpha 0.775 from 18 valid items. The students were asked to indicate their level of agreement with statements via 4-point Likert scale ( $1=$ totally disagree to $4=$ totally agree).

The study was conducted on January to March 2018 in various regions of Jakarta and Depok. Prior to the study, the school teachers informed parents about the study and asked if their child could participate in the study. The researcher described the nature of the research to all of the participants, answered any questions that arose, and asked all students to read and sign the inform consent. All students who were present in class on the day of data collection completed the questionnaire. Students who agreed to participate in the research received the packet of questionnaires to complete during class.

To answer the research question, an independent sample Ttest was conducted. Independent T-test was used because there are two conditions and different participants assigned to each condition [26] Attitude scores were included as dependent variables. At the same time, genders (i.e. boys and girls) were included as the independent variable and were used as a between-subjects factor. For all statistical analysis, a p-value of .05 was considered statistically significant.

\section{RESULT AND DISCUSSION}

\section{A. Descriptive statistics}

Descriptive statistics showed a mean attitude score of $46.68(\mathrm{SD}=4.82)$ of primary school students. Three percents of students indicated to have a negative attitude (score $<37$ ). The majority of students $(95.5 \%)$ showed a score of 37 to 57 , indicating a neutral attitude. Only a small number of students (1.5\%) gave a positive attitude toward students with disabilities. The descriptive statistics for measurement are presented in Table I. 
TABLE I. MEANS AND SDS ON STUDENTS' ATTITUDE TOWARDS STUDENTS WITH DISABILITIES

\begin{tabular}{|l|l|l|c|}
\hline \multirow{2}{*}{ Gender } & \multicolumn{2}{|c|}{ Attitude toward Students with Disabilities } & \multirow{2}{*}{$\begin{array}{c}\text { \% of } \\
\text { total N }\end{array}$} \\
\cline { 2 - 3 } & \multicolumn{1}{|c|}{$\boldsymbol{M}$} & 5.14 & $55.3 \%$ \\
\hline Boys $(n=147)$ & 46.17 & 4.38 & $44.7 \%$ \\
\hline Girls $(n=119)$ & 47.31 & 4.84 & $100 \%$ \\
\hline TOTAL $(\boldsymbol{n}=266)$ & 46.68 & \multicolumn{2}{|c|}{$\boldsymbol{S}$} \\
\hline
\end{tabular}

\section{B. Gender Differences in Attitude Toward Students with Disabilities}

From Table I, we can also see that the boys mean of attitude $(M=46.17, S D=5.14)$ is slightly lower than girls $(M=47.31, S D=4.38)$. Then, the Independent T-test showed that there was no significant difference in attitude scores between boys and girls $\mathrm{t}(264)=-1.921, \mathrm{p}=0.056$. This means that boys and girls have an equal attitude towards the student with disabilities.

In this current study, we aim to compare the differences in attitude toward students with disabilities between boys and girls primary inclusive school in Jakarta. Attitudes were assessed using $\mathrm{CATCH}$, a questionnaire that was adapted into the Bahasa version. Based on the findings, we conclude that boys and girls are held an equal attitude toward students with disabilities. Generally, students held a neutral attitude, with girl's attitude is slightly more positive than boys. Although, the attitude score between both boys and girls are not significantly different.

These findings are not in line with other studies, for example by [27] revealed that girls report more positive attitudes than their boys to the inclusion of their disabled peers. However, this finding helps to change the faulty perception that boys have a more negative attitude toward students with disabilities compared to girls. A possible explanation for this unexpected outcome is the attitude of girls and boys are also influence with other variables, such as the type of disabilities, class size and knowledge about disabilities [10], which are not measured in this study. The other variables might have a more significant influence on attitudes toward students with special needs.

Second, even though there are no significant differences in attitude between boys and girls, the descriptive result showed girls have a slightly more positive attitude toward children with disabilities. This result is in line with another finding, that stated attitudes toward disabilities among boys and girls were alike; however, girls showed a more positive attitude toward particular disabilities, such as physical disabilities, than boys [14]. For instance, the provision of information about physical and intellectual disability may influence the expressed attitudes of boys and girls.

Third, this study only measures attitudes as a unidimensional variable, while the three components of attitude (i.e. cognitive, affective, and behavioral) cannot be measured alone with this measurement. Research from [22] showed that girls have a more positive attitude than boys in the affective and behavioral components, while the cognitive component tends to be the same.
Finally, in this study, we also found that students are indicated with a neutral attitude. This outcome was in line with other research [10]. Despite the overall neutral score, students were also holding far more positive or far more negative attitudes. Hence, it is essential to consider that neutral scores also imply a number of students with negative attitudes. People may start by evaluating a particular attitude object neutrally, but if they form new beliefs connecting the attitude object with particular attributes, consequences, or antecedents, they will move away from neutrality. Some beliefs will be strong and some weak; some will connect the attitude object to positive attributes, others, to negative attributes [19]. This indicates that we strive for more positive attitudes will ultimately lead to a better acceptance of students with disabilities in regular schools.

This study also has some limitations to be improved in future research. Firstly, this study used a self-reported measurement to measure students' attitudes. The use of such a measurement may have resulted in socially desirable responses. With respect to the outcomes of this study, there is a possibility that students might report attitudes that are more or less positive than their attitude actually is.

The second limitation is, compared with other studies, the focus of this study was the gender differences in attitudes with regard to existence or nonexistence of a visible disability. Attitudes are also shaped by other contextual variables, such as causality of the disability or class size.

The other limitation is related to the population of this study which came from the different type of inclusive school, private and public. The experience and knowledge of disabilities between these two types of schools might be different due to the awareness of the students which were facilitated by the teachers. Based on the field observation, it can be assumed that students in private school are assumed to be more aware of disabilities than students in the public school because the teachers are more informative about inclusion.

The following suggestions should be considered for further improvement. (1) To have more reliable results, it is highly recommended to include other measurement tools, such as structured interview and observation in future research. (2) It is suggested to employ additional scenarios in which further information is provided with regard to the context of the person with the disability, such as the type of disabilities, experience with disabilities, and class size. (3) It is highly recommended to examine the differences between students' attitude in the private and public inclusive schools due to the differences in facilitation, class size, and attention toward disability.

\section{REFERENCES}

[1] L. Wisniewski and S. Alper, "Including students with severe disabilities in general education settings: Guidelines for change," Remedial and Special Education, vol. 15, no. 1, pp. 4-13, 1994.

[2] D. P. Hallahan and J. M. Kauffman, Exceptional Learner, 10th ed. Pearson, 2006. Available: www.pearson.com

[3] UNESCO, The Salamanca statement and the framework for action on special needs education. Paris, France, 1994. 
[4] F. Kurniawati, A. Minnaert, F. Mangunsong, and W. Ahmed, "Empirical study on primary school teachers' attitudes towards inclusive education in Jakarta, Indonesia," Procedia - Social and Behavioral Sciences, vol. 69, pp. 1430-1436, 2012.

[5] A. Flem and C. Keller, "Inclusion in Norway: A study of ideology in practice," European Journal of Special Needs Education, vol. 15, no. 2, pp. 188-205, 2000.

[6] N. Kiuru, K. Aunola, M.-K. Lerkkanen, E. Pakarinen, E. Poskiparta, T. Ahonen, A.-M. Poikkeus, and J.-E. Nurmi, "Positive teacher and peer relations combine to predict primary school students' academic skill development.," Developmental Psychology, vol. 51, no. 4, pp. 434-446, Apr. 2015.

[7] F. D. Pratiwi, The Effect of Social Skills on Academic Self-Concept Mediated by Social Support of Students with Special Needs in Inclusive Primary School. Depok: Universitas Indonesia, 2018.

[8] I. P. Darma and B. Rusyidi, "Pelaksanaan sekolah inklusi di Indonesia," Prosiding KS, vol. 2, no. 2, 2016.

[9] S. Schwab, "The impact of contact on students' attitudes towards peers with disabilities," Research in Developmental Disabilities, vol. 62, pp. 160-165, 2017.

[10] A. A. De Boer, S. J. Pijl, and A. E. M. G. Minnaert, "Students' attitudes towards peers with disabilities: A review of the literature. Manuscript accepted for publication," International Journal of Disability, Development and Education, 2012.

[11] E. Avramidis, "Social relationships of pupils with special educationa needs in the mainstream primary class: Peer group membership and peer assessed social behaviour," European Journal of Special Needs Education, vol. 25, no. 4, pp. 413-429, 2010.

[12] M. Koster, S. J. Pijl, H. Nakken, and E. Van Houten, "Socia participation of students with special needs in regular primary education in The Netherlands," International Journal of Disability, Development and Education, vol. 57, no. 1, pp. 59-75, 2010.

[13] H. J. Neckerman, "The stability of social groups in childhood and adolescence: The role of the classroom social environment," Social Development, vol. 5, no. 2, pp. 131-145, 1996.

[14] G. Laws and E. Kelly, "The attitudes and friendship intentions of children in United Kingdom mainstream schools towards peers with physical or intellectual disabilities," International Journal of Disability, Development and Education, vol. 52, no. 2, pp. 79-99, 2005.

[15] E. K. Minde, "A Program Design Model for Teaching Typically Developing Elementary School Students about Physical and Developmental Disabilities: Promoting Acceptance Through
Understanding and Interaction," Doctoral dissertation, University of New Jersey, New Jersey, United States, 2003.

[16] O. Aluede, F. Adeleke, D. Omoike, and J. Afen-Akpaida, "A review of the extent, nature, characteristics and effects of bullying behaviour in schools," Journal of Instructional Psychology, vol. 35, no. 2, pp. 151$158,2008$.

[17] R. Lund, K. K. Nielsen, D. H. Hansen, M. Kriegbaum, D. Molbo, P. Due, and U. Christensen, "Exposure to bullying at school and depression in adulthood: A study of Danish men born in 1953," European Journal of Public Health, vol. 19, no. 1, pp. 111-116, 2009.

[18] K. Petry, "The relationship between class attitudes towards peers with a disability and peer acceptance, friendships and peer interactions of students with a disability in regular secondary schools," European Journal of Special Needs Education, vol. 33, no. 2, pp. 254-268, 2018.

[19] H. C. Triandis, "Attitudes measurement and methodology," in Attitudes and attitude change, H. C. Triandis, Ed. New York: John Wiley \& Sons, 1971, pp. 26-59.

[20] E. A. Nowicki and R. Sandieson, "A meta-analysis of school-age children's attitudes towards persons with physical or intellectual disabilities," International Journal of Disability, Development and Education, vol. 49, no. 3, pp. 243-265, 2002

[21] A. De Boer, S. J. Pijl, A. Minnaert, and W. Post, "Evaluating the effectiveness of an intervention program to influence attitudes of students towards peers with disabilities," Journal of autism and developmental disorders, vol. 44, no. 3, pp. 572-583, 2014.

[22] F. Osmanaga, "The Role Of Gender In Children's Attitudes Towards Pupils With Disabilities," Život $i$ škola: časopis za teoriju $i$ praksu odgoja i obrazovanja, vol. 59, no. 29, pp. 405-418, 2013.

[23] M. Tamm and M. Prellwitz, "If I had a friend in a wheelchair' children's thoughts on disabilities," Child: Care, Health and Development, vol. 27, no. 31, pp. 223-240, 2001

[24] N. Vilchinsky, S. Werner, and L. Findler, "Gender and attitudes toward people using wheelchairs: A multidimensional perspective," Rehabilitation Counseling Bulletin, vol. 53, no. 3, pp. 163-174, 2010.

[25] P. L. Rosenbaum, R. W. Armstrong, and S. M. King, "Determinants of children's attitudes toward disability: A review of evidence," Children's Health Care, vol. 17, no. 1, pp. 32-39, 1985.

[26] A. Field, Discovering statistics using SPSS. Sage Publications Ltd., 2009.

[27] C. Vignes, E. Godeau, M. Sentenac, N. Coley, F. Navarro, H. Grandjean, and C. Arnaud, "Determinants of students' attitudes towards peers with disabilities," Developmental Medicine \& Child Neurology, vol. 51, no. 6, pp. 473-479, 2009. 